Миодраг Сибиновић

\title{
ДОСИТЕЈЕВА КОНЦЕПЦИЈА ПРЕВОЪЕЊА И СРПСКА КЊИЖЕВНОСТ
}

У овој расправи полазимо од сазнања до којих смо дошли у књизи Оригинал и превод (1979): „1. Доситеј у превођењу види пут за бржи и интензивнији развој народа; 2. преводну књижевност, односно књижевност упоште, схвата пре свега као штиво које има дидактичку намену, али ће, истовремено... вршити и естетичку функцију; 3. Доситеј не прави разлику између оригиналног и преводилачког рада, из чега проистиче веома слободан однос према тексту оригинала." (стр. 33) Тада смо дошли до закључка да је Обрадовићева експлицитно изражена концепција превођења класицистичко-просветитељска и да се своди на превод-адаптацију (стр. 51). Приступајући обради значаја Обрадовићеве концепције превођења за развој српске књижевности полазили смо и од сазнања о његовој имплицитној класицистичко-просветитељској поетици, о чему смо писали у новосадском зборнику Копча I (1983).
\end{abstract}

II

Познато је већ да у другој половини XVIII и почетком XIX века код нас ни број писаца, ни њихов састав, као и списак преведених дела из светске књижевности, није импресиван (Абстемиј, Адисон, Бабо, Бланшар, Пренс д'Бомон, Виланд, Виторели, Волчков, Гелерт, Геснер, Голдони, Голдсмит, Гоци, Дефо, Езоп, Енгел, Екарсхаузен, Јован Златоусти, Кампе, Клајст, Коцебу, Лафонтен, Лесинг, Ломоносов, Марколфе, Мармонтел, Николаија, Овидије, Старк, Федар, Фенелон, Флоријан, Херасков, Хердер, Цицерон, Цоликофер, Честерфилд, Самјуел Џонсон, Шилер; са овог списка по два и више пута објављивана су у том периоду дела Пренс 
д’Бомона, Дефоа, Абстемија, Виланда, Езопа, Екартсхаузена, Лафонтена, Лесинга, Марколфеа, Мармонтела, Овидија и Федра.

У нашој старијој књижевноисторијској науци преовладало је мишљење да је ниво српске преводне књижевности овог периода у целини узето веома низак; Стојан Новаковић, Светозар Марковић, Јован Скерлић, Павле Поповић, Никола Андрић, Петар Митропан и други. Њихове оцене су се сводиле на констатације: да избор није обухватио највеће водеће античке, као ни старије и савремене европске писце; да у том избору није било систематичности, него га карактерише произвољност и пука случајност; и најзад, да гро српске преводилачке продукције онога времена испуњавају минорни, другостепени и трећестепени писци, пре свега немачки.

Занимљиво је да се новији истраживачи, не оспоравајући изричито оцене својих претходника, почињу ипак другачије изражавати о српској преводној књижевности краја XVIII - почетка XIX века. Све чешће почињу да констатују да, с обзиром на степен развијености ондашње српске културе и књижевности, другачији избор превода није био ни остварив.

До ове промене је дошло, пре свега, због промене методолошког приступа. Кад су напустили метод позитивистичког пуког евидентирања чињеница, кад се више нису постављали као зналци европске књижевности који осуђују своје старије сународнике што нису уместо Коцебуа преводили Шекспира или Гетеа - него су те чињенице покушали да објашњавају, да тумаче у контексту укупног историјског развоја српског друштва и српске културе, историчари књижевности су и у преводној књижевности, уместо произвољности, „незнања” и несистематичности, почели да назиру логику и законитост укупног тока српског културног и књижевног процеса.

Међутим, значај и функција преводне књижевности у овом периоду, чини нам се, још увек ипак није довољно осветљена. До објективне оцене се није могло доћи због двеју крајности, заснованих, у суштини, на пристрасности... Прва је проистекла из инсистирања на самосвојности, „народности”, националној аутохтоности српске књижевности која је никла и набујала на основама „српске класике”, тј. на основама фолклоpa, пре свега на основама народне поезије. Другу крајност испољавали су компаратисти који су српску књижевност процењивали у светлости одређене стране књижевности, инсистирајући на ономе шта је српска књижевност могла, а ипак није преузимала из стране књижевности...

Сазнања о глобалној друштвеној условљености управо такве преводне књижевности каква је била српска крајем XVIII почетком XIX века 
требало би, међутим, продубити у следећем правцу: потражити одговор на питање шта је управо таква, не много репрезентативна по именима и преведеним делима, управо тако друштвено условљена српска преводна књижевност ипак донела укупном процесу развоја српске културе и српске књижевности. То значи да тежиште разматрања треба да буде на функцији преводне књижевности у српској култури и укупној српској књижевности тога периода. До задовољавајућег резултата у решавању тако постављеног задатка, дакле, може се доћи једино под условом ако се у српској књижевности овог периода тражи оно што је та књижевност садржала, а не оно чега у њој није било.

Па чега је, дакле, у српској књижевности доситејевског периода било? Пре свега, мора се рећи да и међу превођеним писцима, као и међу преведеним делима има и оних који припадају самом врху европске књижевности, или су бар у оно време сматрани врхунским и у културно развијенијим срединама од наше. Пада у очи да су у списку писаца чија су дела до 1820. године у српским преводима објављивана више од једног пута у огромној већини управо писци који нису минорни. Тај списак би се могао и још појачати кад би се узели у обзир писци за које се зна да су их неки наши аутори преводили, иако своје преводе сами нису објавили. Рецимо, Лука Милованов је 1810. као прилог Опиту настављеюа о србској сличноречности и слогомерију или просодији који је, стицајем у књижевној историји познатих чињеница, објављен тек 1833, осим Шајбера и Вајса, с немачког превео чак близу шест стотина Биргерових стихова (тачно 594). То је скоро мала збирчица лирских песама писаца на основу чије Леноре управо током прве деценије XIX века Василиј Жуковски зачиње романтичарску поезију у руској књижевности. Глигорије Трлајић, преводилац Херасковљевог Нуме.., оставио је у рукопису превод Фенелоновог Телемаха и један превод похвале Марка Аурелија. Јована Дошеновића је само пештанска цензура спречила да у своју књигу 1809. године унесе и превод Волтерових стихова. У једну специфичну врсту преводилачке књижевне делатности, такође, могло би се уврстити превођење дела античких писаца у српским латинским школама. Познато је, пак, да се, „од тридесетих година XVIII века”, у тим школама „у оквиру наставе обавезно преводе текстови Езопа, Цицерона, Квинтилијана, Фронтона, Сенеке, Јулија Цезара, Корнелија Непота, Тита Ливија, Овидија, Федра, и других". За проблем о којем говоримо посебно је занимљива једна констатација коју Јован Деретић износи у својој књизи Српски роман, 1850-1950. Наиме, пошавши од тога да је српска књижевност XVIII века Мармонтеловог Велизарија добила само непуних десетак година од његове појаве, а у време кад је био изузетно популаран 
и превођен у готово свим европским књижевностима, а да је 1799. г. добила Дефоов роман Робинсон Крусо, Деретић за Скерлићем сматра да се српска преводна књижевност од почетка XIX века може и овако оценити: „... од почетка XIX века до педесетих година, роман заузима једно од најистакнутијих места у преводној литератури. Иако се највише преводи са немачког, преведеним романима обухваћене су и друге европске литературе: енглеска, француска, руска, мађарска итд. Међу романима који су преведени у том раздобљу налазе се нека од најзначајнијих дела европске романескне литературе као што су: Виландови Абдерићани (1803) и Агатон (1820), Фенелонов Телемах (1814), Волтеров Задиг (1828), Лесажов Жил Блас $(1834,1836)$, Гетеов Вертер $(1844)$ и др.”

Српска преводна књижевност од 70-тих година XVIII века до 1820. године имала је, гледано према подацима које су давали сами преводиоци, преводе са грчког, латинског, немачког, руског, енглеског, француског, мађарског и италијанског језика. Без обзира на то што су неки преводиоци, попут, рецимо, Јоакима Вујића, волели, због рекламе, и да саопштавају да су преводили са енглеског кад су дела енглеских писаца претакали на наш језик са немачког, овај списак се може сматрати веродостојним, јер данас знамо да је било и супротних примера: Доситеј Обрадовић тако, много пута и не наводи да је поједине текстове превео са других језика.

Кад се погледају подаци о српској преводној књижевности од средине XVIII века до 1820, пада у очи још једна изузетно значајна чињеница. Списак преводилаца је, наиме, готово идентичан са списком српских писаца онога времена. Уз то, што је за нашу тему још значајније, код већине њих преводилачки рад даје тон и основну вредност њиховом укупном књижевном делу. Да би се ова констатација проверила, довољно је и само погледати списак, карактеристике и оцене српских писаца овог времена које даје Јован Скерлић у својој Историји нове српске кюижевности (Павла Јулинца, Доситеја Обрадовића, Јована Мушкатировића, Глигорија Трлајића, Вићентија Ракића, Милована Видаковића).

Кад се чита Скерлићева Историја подаци које нам пружа намећу доста јасан закључак да има основа за тврдњу да су се у овом периоду на подручју преводне книжевности заправо формирали и развијали први писци нове српске књижевности. За Видаковића, кога претходно карактерише као компилатора, Скерлић каже: „Тај популарни писац створио је српски роман и за дуго време задовољавао скромне књижевне потребе ондашње публике српске." Ова формулација се може проширити и на функцију целокупне српске преводне књижевности раздобља о којем говоримо. Она је, и то пре свега она, задовољавала „скромне књижевне 
потребе ондашње публике српске”. Међутим, ни тиме се не исцрпљују све њене функције. Значај српске преводне књижевности у овој фази развоја српске литературе знатно је шири и дубљи.

Ка конкретизацији закључка о том ширем и дубљем значају српске преводне књижевности овога периода води нас више сазнања која се могу ишчитати, осим код Скерлића, и из Павићеве Историје српске кғижевности класицизма и предромантизма у одељку Жанровска обнова српског песништва (иако сам аутор такав закључак не изводи). Кад говори о оди као најрепрезентативнијем песничком облику у књижевности класицизма, Павић, поред осталог, тврди: „У кругу Лукијана Мушицког она је наслеђена из XVIII века, од прве генерације класициста. Јавила се још 1734. године (Ода Дунаву), а проноксирао ју је већ први класицистички песник српски Алексије Везилић 1758. године. Он се формом везао за Хорацијеве оде у сафијским строфама, од којих је чувену Integer vitae парафразирао, или преводио, па је она оставила траг и на наслову његове књиге Краткое написаније о спокојној жизни." О утемељењу жанра елегије у српској књижевности Павић пише: „Катулови надгробни епиграми развијени до кратке елегије, елегија неотерика и Тибулове елегије, које познаје Пачић и преводи Василије Суботић... то су све извори елегије српског класицизма. Посебно место међу овим узорима има у српском класицизму Овидијева елегија коју преводе Мразовић, В. Суботић и Стерија." О епистолама као жанру у српској књижевности Павић ће рећи: „Оне су инспирисане Овидијевим посланицама, које су рано биле преведене у српској класицистичкој књижевности, а још раније по школама XVIII века постале предмет ђачких вежбања, као што је случај и с Хорацијевим песничким писмима."

На основу оваквих чињеница можемо закључити да је српска преводна књижевност у овом периоду имала пресудну улогу у утемељењу водећих жанрова укупне српске књижевности коју Скерлић назива „новом". Овај закључак потврђују такође и подаци о путевима и дометима српске сентименталистичке и предромантичарске књижевности. Преведена дела одговарајућих жанрова немају значај само као готови узори на српском језику. За развој нове српске књижевности исто толики значај имао је и сам процес превођења појединих дела у којем су тражена и развијена одговарајућа изражајна средства. И тај рад је имао смисао поступног унутрашњег развоја који српску књижевност, асимиловањем одређених већ освојених тековина европске и светске литературе, води ка нивоу изједначавања са песничким дометима најразвијенијих литература других народа. Чак и онда кад развој српске књижевности пође неким својим особеним токовима, као у области документарних жанрова, 
или пак, за време романтизма, кад се програмски надовезује на усмену народну књижевност.

Кад је реч о избору дела за превођење, осим онога што смо већ констатовали, неопходно је обратити пажњу још на следећу чињеницу. Један од важних закључака међу онима који се доживљавају као основ за негативну оцену српске преводне књижевности овог периода је, иначе тачан податак, да смо већину и оних дела европске књижевности из реда врхунских по вредности која су у преводима и дошла до нас - добили из различитих прерада, претежно немачких, из XVIII или са почетка XIX века. Питање односа дела из старије и савремене књижевне продукције која улазе у преводну књижевност занимљиво је и у ширем теоријском погледу. Пошто је, по природи ствари, окренута претежно провереним вредностима, преводна књижевност се априори сматра конзервативном. Међутим, управо подаци о ситуацији у српској преводној књижевности са почетка XIX века бацају другачију светлост на ову врсту литературе: чињеница да се, уместо старих изворних оригинала, преводе њихове немачке и друге прераде које су израз актуелних естетичких и стилских књижевних токова, сведочи о томе да је, с обзиром на степен развијености ондашње српске књижевности, та преводна књижевност била заправо у шпицу укупне српске лепе књижевности. Али и не само то.

Пажљивом погледу не може измаћи још једна изузетно значајна функција српске преводне књижевности краја XVIII - почетка XIX века. Она постаје и грађа којом се твори српска оригинална књижевност. Та се функција могла наслутити готово програмски декларативно из оног не малог броја превода које су преводиоци често објављивали без имена писаца оригинала, па и без назнаке да је дело које штампају преведено са неког страног језика. Навешћемо неколике примере.

Емануило Јанковић је Голдонијеве Трговце објавио са отвореном жељом да тим текстом створи позитиван однос српске публике према драми уопште као књижевном роду. Хтео је показати да су и комедије поучна и корисна књижевна дела, да није тачно да су их „ђаволи Шваби измислили, како би изварали новце од људи”. После две године, 1789, објавио је прво превод позоришне игре за децу од немачког писца Франца Ксавера Старка Зао отаи и невальао син, а онда, те исте године, и сеоску веселу игру у једном чину Благодарни син, која је све до деведесетих година XIX века сматрана Јанковићевим оригиналним делом. Стојан Новаковић, рецимо, у својој Историји српске кюижевности истиче Благодарног сина као прву српску оригиналну комедију. Међутим, не би се могло рећи да је Јанковић Благодарним сином извршио мистификацију. Неправедно би било окривити га за плагијат, јер у предговору издања 
Злог оца и невальалог сина најавио је да има „још једну наравоучитељну комедију преведену”. Чак и у наслову Благодарног сина означава: „стављено на просто српски". Међутим, очигледно није сматрао за потребно да наводи име писца и даје податке о немачком изворнику. Јован Скерлић је о Миловану Видаковићу у својој Историји нове српске књижевности, поред осталог, написао: „Видаковић је писац слабе оригиналности и његови романи су не само угледања на популарне немачке ритерске приче и филозофско-педагошке романе но често проста прерађивања, посрбљавања. За Касију иарииу је утврђено да је превод средњевековног романа Kaiser Octavianus, за Силоана и Милену сам Видаковић вели да је 'изображена из једне самочувене приповетке. И то ће се, доцнијим књижевним истраживањима, утврдити за друге његове романе”. Павле Поповић је у својој књизи Милован Видаковић све ове проблеме анализирао знатно шире и детаљније. Занимљиво је да се проблем превода као грађе из које настају и дела оригиналне књижевности назире и у Поповићевој књизи, мада Поповић ту материју посматра са становишта класичне позитивистичке компаратистике - трагајући за страним „утицајима” у Видаковићевом делу.

Ове чињенице нису нимало безначајне, ако се зна да је реч о некада веома популарном писцу, који је „створио... српски роман и за дуго време задовољавао скромне књижевне потребе ондашње публике српске.”; чији је „утицај био... врло велики.” Међутим, можда би се наведеним примерима као аргументима за тезу да је преводна књижевност у доситејевско време представљала и грађу за стварање оригиналне српске књижевности могло приговорити да су и Јанковић, и Вујић, и Видаковић књижевници чија дела ипак не спадају у врхунска остварења српске литературе. Додуше, на тај приговор би се могло одговорити да у оно време, ако се изузму Обрадовић и, касније, Мушицки, бољих писаца у српској књижевности није ни било. Али значајнији аргумент у прилог изнесене тезе о овој функцији преводне књижевности можемо наћи у првој фази књижевног рада Јована Стерије Поповића, као писца у чију врхунску вредност за српску књижевност XIX века нема одиста никакве сумње.

У закључку, бисмо, међутим, морали приметити још следеће: иза коришћења превода као грађе за оригинална дела српске књижевности се не крије недостатак талента писаца и наивност публике, како је то раније често тумачено. Оно проистиче из, од античких времена старе, а у европској књижевности XVII и XVIII века обновљене, филозофске концепције књижевности као мимезе. Ова концепција је, као што је познато, још од Аристотела и Хорација, а нарочито у време кад се у класицизму 
или неокласицизму новога времена Аристотелова и Хорацијева поетика актуализују, подразумевала у уметничком раду подражавање како природи, тако исто и делима признатих великих уметника. На таквој основи развила се широко распрострањена миметички усмерена књижевност, чијем току припада како Доситејева концепција превођења, тако и српска литература доситејевског времена. 